\title{
DAYA TERIMA, KADAR PROTEIN, KADAR LIPID DAN JUMLAH MIKROBA PADA KEFIR SUSU SAPI DAN KEFIR SUSU KAMBING SEBAGAI ALTERNATIF MINUMAN PROBIOTIK
}

\author{
Ratu Ayu Istawa1, Roifah Fajri2*, Dedi Zaenal Arifin³ \\ 1,2,3 Sekolah Tinggi Ilmu Kesehatan Holistik \\ *Korespondensi: Jl. Veteran No.272 Ciseureuh Purwakarta, Email: roifahf@gmail.com
}

\begin{abstract}
ABSTRAK
Latar Belakang: Di Indonesia, gangguan sistem pencernaan makanan khususnya diare terjadi sebanyak 6.897.463 kasus pada tahun 2006. Salah satu faktor penyebab gangguan sistem pencernaan adalah asupan makanan. Alternatif pencegahan gangguan sistem pencernaan antara lain adalah dengan konsumsi pangan fungsional yaitu minuman probiotik seperti kefir. Kefir merupakan pangan fungsional karena mengandung probiotik yang baik untuk sistem pencernaan.

Tujuan Penelitian: Menganalisis daya terima, kadar protein, kadar lipid dan jumlah mikroba pada kefir susu sapi dibandingkan dengan kefir susu kambing.

Metode: Penelitian ini adalah penelitian kuantitatif menggunakan RAL (Rancangan Acak Lengkap) dengan 1 faktor yaitu perbedaan jenis susu yang digunakan dalam pembuatan kefir dengan 3 kali ulangan perlakuan. Penelitian terdiri dari 3 tahap yaitu pembuatan kefir, uji daya terima, serta uji kimia dan mikrobiologi (kadar protein, kadar lipid dan jumlah mikroba). Analisis statistik dilakukan dengan meggunakan uji beda sampel dan uji Mann Whitney.

Hasil: Tidak ada perbedaan daya terima antara kefir susu sapi dan kefir susu kambing pada parameter warna, aroma, rasa, dan tekstur. Kadar protein kefir susu sapi $(3,40+0,21 \%)$ dan kefir susu kambing $(4,28+0,36 \%)$ berbeda nyata dengan nilai $\mathrm{p}<0,05$. Sedangkan kadar lipid kefir susu sapi $(3,24+0,03 \%)$ dengan kefir susu kambing $(3,69+0,02 \%)$ berbeda nyata dengan nilai $\mathrm{p}<0,05$. Begitu pula dengan jumlah mikroba kefir susu sapi $(3,11 \times 106 \mathrm{koloni} / \mathrm{ml})$ dan kefir susu kambing $(12,36 \times 106 \mathrm{koloni} / \mathrm{ml})$ berbeda nyata dengan nilai $\mathrm{p}<0,05$.

Simpulan: Kadar protein, kadar lemak dan jumlah mikroba kefir susu kambing lebih tinggi dibandingkan kefir susu sapi. Tidak ada perbedaan daya terima antara kefir susu sapi dengan kefir susu kambing.
\end{abstract}

Kata kunci: kefir, protein, lemak, daya terima, jumlah mikroba

\begin{abstract}
Background: In Indonesia, indigestion issue specifically diarrhe was 6,897,463 cases in 2006. One of the factors causing indigestion issue is food intake. An alternative to prevent digestive problems is consumption of functional foods such as probiotic drink i.e. kefir. Kefir is a functional food because of probiotic content that are good for the digestive system.

Objective: To analyze the acceptability, protein content, lipid content and microbial content of cow milk kefir compared to goat milk kefir.

Method: This research is a quantitative study using CRD (Completely Randomized Design) with one factor, i.e. the difference of milk type used in the kefir. The study consisted of the kefir production stage, acceptance analysis stage, and protein, lipid and microbial content analysis stage.

Result: There was no difference acceptability between cow milk kefir and goat milk kefir on the color, flavor, taste and texture parameter. There is a difference in protein content between cow milk kefir (3,40 $\pm 0,21 \%)$ and goat milk kefir $(4,28 \pm 0,36 \%)$ with $p$ value $<0,05$. At the lipid content, there is a difference between cow milk kefir $(3,24 \pm 0,03 \%)$ and goat milk kefir $(3,69 \pm$ $0,02 \%)$ with $p$ p value<0,05. Similiarly result shown at microbial content, there is a difference between cow milk kefir $\left(3,11 \times 10^{6} \mathrm{cfu} / \mathrm{ml}\right)$ and goat milk kefir $\left(12,36 \times 10^{6} \mathrm{cfu} / \mathrm{ml}\right)$ with $p$ value $<0,05$.
\end{abstract}

Conclusion: Cow milk kefir have a higher protein, lipid and microbial content than goat milk kefir. There is no difference in acceptability between cow milk kefir and goat milk kefir. 
Keywords: kefir, protein, fat, acceptability, microbial content

\begin{abstract}
PENDAHULUAN
Sistem pencernaan merupakan gerbang utama masuknya zat gizi sebagai sumber pemenuhan kebutuhan tubuh dalam proses metabolisme. Lambung merupakan tempat mencerna makanan untuk diserap sebagai zat gizi, oleh sebab itu kesehatan lambung menjadi hal yang sangat penting dalam optimalisasi pencernaan dan penyerapan gizi. ${ }^{1} \mathrm{Di}$ Indonesia gangguan sistem pencernaan yang sering ditemukan disebabkan oleh faktor makanan, kesehatan, lingkungan, infeksi atau alergi pada protein susu sapi. Pemberian asupan nutrisi yang cukup sangat penting guna memelihara kesehatan pencernaan, salah satu caranya dengan mengkonsumsi secara rutin minuman probiotik sebagai makanan fungsional. ${ }^{2}$ Kasus kejadian diare pada tahun 2016 di Indonesia sebanyak 6.897.463 kasus. ${ }^{3}$
\end{abstract}

Pangan fungsional adalah pangan yang secara alamiah maupun telah mengalami proses, memiliki satu atau lebih senyawa yang berdasarkan kajian-kajian ilmiah dianggap memiliki fungsi fisiologis tertentu yang bermanfaat bagi kesehatan pencernaan. ${ }^{4}$ Salah satu produk pangan fungsional yang banyak dikonsumsi adalah minuman probiotik. Minuman probiotik adalah minuman yang mengandung bakteri baik dan menguntungkan bagi saluran pencernaan karena dapat meningkatkan keseimbangan mikroflora usus dan mampu bertahan hidup dalam keasaman lambung sehingga dapat menempati usus dalam kuantitas yang cukup besar serta dapat menghambat bakteri patogen. ${ }^{5}$

Kefir merupakan salah satu minuman probiotik karena mengandung mikroba yang baik untuk sistem pencernaan. Kefir mengandung probiotik penghasil senyawa antimikroba seperti bakteriosin, hidrogen peroksida dan berbagai antibiotik yang menekan pertumbuhan bakteri penyebab penyakit saluran pencernaan, meningkatkan fungsi pencernaan dan penyerapan nutrisi makanan serta membantu mengatasi konstipasi. ${ }^{6}$

Susu merupakan sumber kalsium paling baik, karena di samping kadar kalsium yang tinggi, laktosa di dalam susu membantu absorpsi susu di dalam saluran cerna. ${ }^{7}$ Mutu protein susu sepadan nilainya dengan protein daging dan telur, dan kaya akan lisin, salah satu asam amino esensial yang dibutuhkan tubuh. ${ }^{8}$

Protein merupakan salah satu kandungan dalam susu segar yang dibutuhkan oleh tubuh manusia. ${ }^{9}$ Kandungan protein kefir lebih mudah dicerna dibandingkan dengan protein susu segar. Sifat fungsional kefir dipengaruhi oleh sifat dari susu yang digunakan dalam proses pembuatannya. Seperti yang disebutkan oleh Surono (2004) bahwa susu sapi dan susu kambing memiliki kandungan yang berbeda sehingga kefir yang dihasilkan juga memiliki kemampuan yang berbeda. ${ }^{10}$

Lemak terkandung dalam kefir secara alami karena bahan utama dalam pembuatannya adalah susu yang mengandung lemak. Kadar lemak di dalam kefir lebih rendah daripada kadar lemak dalam susu segar karena lemak dalam kefir telah dihidrolisis oleh mikroba penghasil enzim lipase. ${ }^{11}$

Berdasarkan uraian diatas, maka peneliti akan mengkaji tentang potensi kefir susu sapi dan kefir susu kambing sebagai alternatif minuman probiotik. Tujuan penelitian ini adalah untuk mengetahui daya terima, kadar protein, kadar lipid dan jumlah mikroba kefir susu sapi dibandingkan dengan kefir susu kambing.

\section{METODE PENELITIAN}

Penelitian ini adalah penelitian kuantitatif. Rancangan percobaan yang menggunakan Rancangan Acak Lengkap (RAL) dengan satu faktor yaitu perbedaan jenis susu yang digunakan dalam pembuatan kefir dengan 3 kali pengulangan perlakuan. Analisis yang dilakukan meliputi analisis daya terima terhadap parameter warna, aroma, rasa dan tekstur. Analisis kimia berupa kadar protein dan kadar lipid serta analisis mikro yaitu jumlah total mikroba. Analisis daya terima dilakukan dengan menggunakan uji pembedaan terhadap parameter warna, aroma, rasa dan tekstur. Analisis kadar protein dengan uji kjeldahl, kadar lipid dengan uji ekstraksi 
soxhlet dan analisis jumlah mikroba dengan uji Total Plate Count. Data yang diperoleh kemudian dianalisa statistik menggunakan metode Uji Beda Sampel (Compare Mean) dengan signifikansi $a=0,05$.
HASIL PENELITIAN

1. Daya Terima

Tabel 4.1 Hasil Analisis Daya Terima pada Kefir Susu Sapi dan Kefir Susu Kambing

\begin{tabular}{ccccc}
\hline & \multicolumn{4}{c}{ Rerata } \\
Perlakuan & Warna & Aroma & Rasa & Tekstur \\
P1 & $3,68 \pm 0,61$ & $3,16 \pm 1,01$ & $2,73 \pm 0,78$ & $3,56 \pm 0,77$ \\
P2 & $3,73 \pm 0,63$ & $3,40 \pm 1,03$ & $2,63 \pm 0,85$ & $3,86 \pm 0,62$ \\
\hline & $\mathrm{P}=0,519$ & $\mathrm{P}=0,403$ & $\mathrm{P}=0,635$ & $\mathrm{P}=0,154$
\end{tabular}

Keterangan: P1 = kefir susu sapi, P2 = kefir susu kambing

Berdasarkan Tabel 4.1 diatas hasil daya terima pada parameter warna diperoleh $\mathrm{P}$ value 0,519 , rata-rata $\mathrm{P} 13,68$ dan rata-rata P2 3,73. Pada parameter aroma diperoleh $\mathrm{P}$ value 0,403 , rata-rata $\mathrm{P} 1$ 3,16 dan rata-rata $P 2$ 3,40. Pada parameter rasa diperoleh $\mathrm{P}$ value 0,635 , rata-rata $\mathrm{P} 1$ 2,73 dan rata-rata P2 2,63. Dan pada parameter tekstur diperoleh $\mathrm{P}$ value 0,154 , rata-rata P1 3,56 dan rata-rata P2 3,86.
Tabel 4.1 menunjukkan bahwa hasil analisis daya terima warna, aroma, rasa dan tekstur pada kefir susu sapi P1 dan kefir susu kambing P2 tidak menunjukkan perbedaan yang nyata $(\mathrm{P}>0,05)$. Hal ini menunjukkan bahwa jenis susu tidak berpengaruh terhadap daya terima kefir, baik dari parameter warna, aroma, rasa dan tekstur.

\section{Kadar Protein, Kadar Lipid dan Jumlah} Mikroba

Tabel 4.2 Hasil Analisis Kadar Protein, Kadar Lipid dan Jumlah Mikroba Kefir Susu Sapi dan Kefir Susu Kambing

\begin{tabular}{|c|c|c|c|}
\hline $\begin{array}{l}\text { Perlakuan } \\
\quad \text { P1 }\end{array}$ & $\begin{array}{c}\text { Kadar Protein }(\%) \\
3,40 \pm 0,21\end{array}$ & $\begin{array}{c}\text { Kadar Lipid (\%) } \\
\quad 3,24 \pm 0,03\end{array}$ & $\begin{array}{c}\text { Aktivitas Probiotik (CFU/ml) } \\
\qquad 3,11 \times 10^{6} \pm 1,45\end{array}$ \\
\hline $\mathrm{P} 2$ & $4,28 \pm 0,36$ & $3,69 \pm 0,02$ & $12,36 \times 10^{6} \pm 0,49$ \\
\hline & $\begin{array}{c}\mathbf{P}=\mathbf{0 , 0 3 3} \\
\text { eterangan } \cdot \mathrm{P} 1=\mathrm{k}\end{array}$ & $\begin{array}{c}\mathbf{P}<\mathbf{0 , 0 0 1} \\
\text { susu sani P2 }=\end{array}$ & $\begin{array}{l}\mathbf{P}=\mathbf{0 , 0 1 4} \\
\text { efir susu kambing }\end{array}$ \\
\hline
\end{tabular}

Berdasarkan Tabel 4.2 hasil analisis kadar protein diperoleh $\mathrm{P}$ value 0,033 dengan rata-rata P2 4,28 lebih tinggi daripada rata-rata P1 3,40. Hasil analisis kadar lipid diperoleh $\mathrm{P}$ value 0,001 dengan rata-rata $\mathrm{P} 2$ 3,69 lebih tinggi daripada ratarata P1 3,24. Dan hasil analisis aktivitas probiotik diperoleh $\mathrm{P}$ value 0,014 dengan

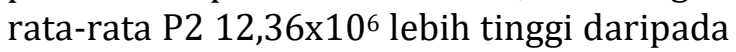
rata-rata $P 1 \quad 3,11 \times 10^{6}$. Tabel $\mathbf{4 . 2}$ menunjukkan bahwa analisis kadar protein, kadar lipid dan aktivitas probiotik pada kefir susu sapi P1 dan kefir susu kambing $\mathrm{P} 2$ terdapat perbedaan nyata $(\mathrm{P}<0,05)$.

\section{PEMBAHASAN}

\section{Daya Terima}

a. Warna

Warna merupakan visualisasi suatu produk yang langsung terlihat lebih dahulu dibandingkan dengan variabel lainnya.
Warna secara langsung akan memengaruhi persepsi panelis. ${ }^{9}$ Hasil analisis daya terima warna menunjukkan tidak ada beda nyata antara kefir susu sapi dan kefir susu kambing. Warna kefir yang dihasilkan sama dan dominan seperti warna susu, yaitu putih pucat sehingga terlihat kurang menarik bagi panelis. Warna putih pada air susu disebabkan karena warna kasein. Warna kasein yang murni berwarna putih seperti salju. Di dalam susu, kasein ini merupakan dispersi koloid sehingga tidak tembus cahaya yang mengakibatkan air susu tersebut berwarna putih. ${ }^{12}$

\section{b. Aroma}

Aroma merupakan reaksi dari makanan yang akan mempengaruhi konsumen sebelum konsumen menikmati makanan, karena konsumen secara refleks akan dapat langsung mencium aroma 
makanan tersebut. ${ }^{13}$ Dari hasil analisis daya terima aroma diperoleh tidak ada beda nyata antara kefir susu sapi dan kefir susu kambing. Aroma kefir yang dihasilkan sedikit agak apek dan asam. Karbondioksida diproduksi oleh starter (bibit kefir) menghasilkan asam laktat, karbondioksida, etanol, asetaldehid dan diasetil serta asam aseton sehingga menghasilkan flavor dan aroma khas pada kefir. ${ }^{14}$ Hal ini sejalan dengan penelitian Setyawardani (2017) yang menunjukkan bahwa kefir yang dihasilkan beraroma asam khas susu fermentasi yang bersumber dari asam lemak susu. ${ }^{15}$

\section{c. Rasa}

Hasil analisis daya terima pada parameter rasa menunjukkan tidak ada beda nyata antara kefir susu sapi dan kefir susu kambing. Produk kefir yang dihasilkan memiliki citarasa asam yang dihasilkan dari proses fermentasi susu dan bibit kefir. Hal ini sejalan dengan pemaparan Zakaria (2009) yaitu kefir adalah produk susu fermentasi yang mempunyai rasa yang spesifik sebagai hasil fermentasi bakteri asam laktat dan khamir yang hidup bersama sama dan saling menguntungkan. ${ }^{16}$ Rasa susu fermentasi (kefir) didominasi rasa asam yang disebabkan oleh aktivitas bakteri asam laktat yang timbul pada proses fermentasi laktosa oleh starter.

\section{d. Tekstur}

Hasil analisis daya terima pada parameter tekstur menunjukkan tidak ada beda nyata antara kefir susu sapi dan kefir susu kambing. Tekstur kefir yang dihasilkan cair seperti tesktur minuman pada umumnya, dengan khas warna putih sehingga terlihat seperti susu. Menurut Kok-tas dkk (2013), mikroorganisme dalam kefir memproduksi eksopolisakarida (EPS) yang dapat mempengaruhi tekstur dan rasa produk. ${ }^{17}$ Eksopolisakarida merupakan salah satu produk bioaktif yang dihasilkan oleh mikroorganisme.

\section{Analisis Kadar Protein, Kadar Lipid dan Aktivitas Probiotik a. Kadar Protein}

Dari hasil analisis diperoleh rata-rata kadar protein dari kefir susu kambing
$4,28 \%$ adalah nyata lebih tinggi dibandingkan kefir susu sapi $3,40 \%$. Tingginya kandungan protein kefir susu kambing karena kandungan susu segarnyapun lebih tinggi. Perbedaan kandungan protein sebagai bahan dasar menyebabkan perbedaan mutu produk. ${ }^{18}$

Kandungan kadar protein pada kefir susu sapi rata-rata $3,40 \%$ meningkat dibandingkan kandungan kadar protein dalam susu sapi segar 3,30\%.19 Dan kandungan kadar protein kefir susu kambing rata-rata $4,28 \%$ meningkat dibandingkan kandungan kadar protein dalam susu kambing segar 3,80\%. ${ }^{20}$ Proses fermentasi membuat kandungan protein dalam kefir lebih mudah dicerna dibandingkan dengan protein susu segar (10). Protein berperanan penting dalam pembentukan biomolekul, menyusun lebih dari separuh bagian sel serta menentukan ukuran dan struktur sel di dalam tubuh manusia. $^{21}$

\section{b. Kadar Lipid}

Ada perbedaan antara kefir susu sapi dan kefir susu kambing dengan nilai ratarata kadar protein kefir susu kambing $3,69 \%$ lebih tinggi daripada nilai rata-rata kadar protein kefir susu sapi 3,24\%. Tingginya kadar lipid dikarenakan kandungan susu kambing segar lebih tinggi dibandingkan susu sapi segar. Kadar lipid merupakan salah satu parameter penentuan kualitas bahan pangan, diantaranya kefir. Kadar lemak di dalam kefir lebih rendah daripada kadar lemak dalam susu segar karena lemak dalam kefir telah dihidrolisis oleh mikroba. ${ }^{11}$

Kandungan kadar lipid susu sapi segar $3,60 \%$ menurun dibandingkan dengan kadar lipid kefir susu sapi rata-rata $3,24 \%$ (19). Dan kandungan kadar lipid susu kambing segar $\quad 4,20 \%$ menurun dibandingkan dengan kadar lipid dalam kefir susu kambing rata-rata 3,69\%. ${ }^{21}$ Lemak dibutuhkan di dalam tubuh karena berfungsi sebagai sumber energi utama dalam proses metabolisme tubuh..$^{22}$

\section{c. Jumlah Mikroba}

Dari hasil analisis diperoleh rata-rata aktivitas probiotik dari kefir susu kambing $12,36 \times 10^{6} \mathrm{cfu} / \mathrm{ml}$ adalah nyata lebih tinggi 
dibandingkan kefir susu sapi 3,11 x $10^{6}$ $\mathrm{cfu} / \mathrm{ml}$. Hal ini disebabkan perbedaan kandungan karbohidrat (laktosa) pada jenis susu yang digunakan pada proses pembuatan kefir. Semakin tinggi kandungan laktosa pada susu maka semakin besar jumlah mikroba yang tumbuh. Hal ini sesuai dengan penelitian yang dilakukan oleh Van den Berg (1988) yang menyatakan bahwa laktosa dalam susu sapi sebanyak $4,7 \%$ dan pada susu kambing sebanyak $4,8 \%{ }^{23}$

Menurut Muchtadi dan Sugiyono (1992), hidrolisa karbohidrat baik oleh asam atau enzim akan menyebabkan menurunnya $\mathrm{pH}$ sehingga semakin banyak karbohidrat yang dihirolisis akan semakin rendah $\mathrm{pH}$ dan menyebabkan aktivitas antibakteri akan lebih tinggi.24 Hal ini sejalan dengan penjelasan Fanworth (2005) yaitu komponen antibakteri juga dihasilkan selama fermentasi kefir seperti asam organik (asam laktat dan asetat), karbondioksida, hidrogen peroksida, etanol, diacetil dan peptida yang berguna untuk menghambat pertumbuhan bakteri patogen serta berguna untuk pencegahan gangguan pencernaan dan infeksi. ${ }^{25}$

\section{SIMPULAN}

Tidak terdapat perbedaan daya terima kefir susu sapi dan kefir susu kambing pada semua parameter yaitu warna, aroma, rasa, dan tekstur. Kadar protein, kadar lipid dan jumlah mikroba yang terkandung pada kefir susu kambing lebih tinggi dibandingkan kefir susu sapi.

\section{DAFTAR PUSTAKA}

1. Anggita N. 2012. Hubungan Faktor Konsumsi dan Karakteristik Individu Dengan Persepsi Gangguan Lambung pada Mahasiswa Penderita Gangguan Lambung di Pusat Kesehatan Mahasiswa (PKM) Universitas Indonesia Tahun 2011. http://lib.ui.ac.id (Diakses 15 Juli 2018).

2. Rachman, Abdul (2011). Gangguan Sistem Pencernaan Pada Bayi. http://www.pucebebe.com/Blog/Gang guan_Pencernaan_Pada_Bayi.2011. [Diakses 12 Juni 2018]

3. Departemen Kesehatan RI. 2011. Buku Saku Diare Edisi 2011. Jakarta: Departemen Kesehatan RI.
4. Herlina, E., dan Nuraeni, F. 2014. Pengembangan Produk Pangan Fungsional Berbasis Ubi Kayu (Manihot esculenta) dalam Menunjang Ketahanan Pangan. Bogor: Program Studi Kimia. Universitas Pakuan. Vol. 3 No. 2: 142148.

5. Rusilanti. 2006. Menu Bergizi untuk Ibu Hamil. Jakarta: Kawan Pustaka.

6. Bahar, Burhan. 2008. Kefir Minuman Susu Fermentasi. Jakarta: PT Gramedia Pustaka Utama.

7. Almatsier,S. 2002. Prinsip Dasar Ilmu Gizi. Penerbit PT Gramedia Pustaka Utama. Jakarta.

8. Widodo W. 2002. Bioteknologi Fermentasi Susu. Malang. Pusat Pengembangan Bioteknologi Universitas Muhammadiyah Malang.

9. Winarno F.G. 2004. Kimia Pangan dan Gizi. PT Gramedia Pustaka Utama. Jakarta.

10. Surono, I.S. 2004. Probiotik, Susu Fermentasi dan Kesehatan. Yayasan Pengusaha Makanan dan Minuman Seluruh Indonesia (YAPMMI). TRICK. Jakarta.

11. Hidayat, A. A. A. (2006). Pengantar Kebutuhan Dasar Manusia: Aplikasi Konsep dan Proses Keperawatan. Jakarta. Salemba Medika.

12. Buda, IK., I. B. Arka, IK. Sulandra, IG. P. Jamasuta dan IK. Arnawa. 1980. Susu dan Hasil Pengolahannya. Bagian Teknologi Hasil Ternak. Fakultas Kedokteran Hewan dan Peternakan. Universitas Udayana. Denpasar

13. Fiani S., Margaretha dan Japarianto, Edwin. 2012. Analisa Pengaruh Food Quality dan Brand Image Terhadap Keputusan Pembelian Roti Kecik Toko Roti Ganep's Di Kota Solo. Jurnal Manajemen Pemasaran, Vol. 1, No. 1: 16

14. Beshkova, D., E. Simova, G. Frengova, Z. Simov, and Z. P. Dimitrov. 2003. Production of Volatile Aroma Compounds by Kefir Starter Cultures. Int. Dairy. J. 13: 529-535.

15. Setyawardani, triana dkk. 2017. Kualitas Kimia, Fisik dan Sensori Kefir Susu Kambing yang Dusimpan pada Suhu dan Lama Penyimpanan Berbeda. Fakultas peternakan universitas 
jendral sudirman purwokerto. Buletin peternakan Vol. 41

16. Zakaria, Y. 2009. "Pengaruh Jenis Susu dan Persentase Starter yang Berbeda terhadap Kualitas Kefir". Agripet : Vol (9) No. 1: 26-30

17. Kok-Tas, T., Seydim, A. C., Ozer, B., dan Guzel-Seydim, Z. B. 2013. Effeccts of Different Fermentation Parameters on Quality Characteristics of Kefir. J. Dairy Sci. 96: 780-789.

18. Sellars, R.L. 1981. Fermented dairy foods. J. Dairy Sci. 64: 1070-1084.

19. Ariani, Ni Luh Sri Novi. 2016. "Karakteristik Kimia Produk Susu Fermentasi "Kefir" Berantioksidan Selama Penyimpanan". Fakultas Peternakan Universitas Udayana Denpasar.

20. Afriananda, Rifki. 2012. "Pengaruh Penambahan Sukrosa dan Glukosa pada Pembuatan Permen Karamel Susu Kambing terhadap Sifat Kimia, Mikrobiologi dan Organoleptik". Fakultas Pertanian Universistas Lampung. Bandar Lampung.
21. Cakrawati dan Mustika NH, Dewi. 2012. Bahan Pangan, Gizi ,Dan Kesehatan. Bandung : Alfabeta.

22. Madja. 2007. Lemak Dalam Tubuh. Diakses pada tanggal 14 Juli 2018 dari http://madja.wordpress.com/2015/05 /02 lemak-dalam-tubuh.

23. Van Den Berg, J. C. T. 1988. Dairy Technology in the Tropics and Subtropic. Pudoc Wegenigen, Netherlands.

24. Muchtadi, Tien R. dan Sugiyono. 1992. Ilmu Pengetahuan Bahan Pangan. IPB. Bogor.

25. Farnworth, E. R. 2005. Kefir $-A$ Complex Probiotic. Food Science \&Technology Bulletin:Functional Foods (1): 1-17. 